\title{
The effect of fungicide dose rate and mixtures on Zymoseptoria tritici in two cultivars of autumn sown wheat
}

\author{
J.B. Drummond ${ }^{1}$, R.A. Craigie ${ }^{1}$, M. Braithwaite ${ }^{2}$, A.T. Gillum ${ }^{3}$ and B.L. McCloy ${ }^{4}$ \\ ${ }^{1}$ Foundation for Arable Research, PO Box 23133, Templeton, Christchurch, New Zealand \\ ${ }^{2}$ Plant Diagnostics Limited, PO Box 23122, Templeton, Christchurch, New Zealand \\ ${ }^{3} P G G$ Wrightson Grain, Kimihia Research Centre, 742 Tancreds Road, Lincoln, New Zealand \\ ${ }^{4}$ New Zealand Arable, PO Box 16144, Christchurch, New Zealand \\ Corresponding author: drummondj@far.org.nz
}

\begin{abstract}
In the 2012-13 and 2013-14 seasons septoria tritici blotch (STB) caused by the fungal pathogen Zymoseptoria tritici was poorly controlled in autumn sown wheat in Canterbury. In 2014-15, a low disease pressure season, three trials were conducted to define the protectant and curative properties of two applications of triazole demethylation inhibitor inhibitor (DMI) and succinate dehydrogenase inhibitor (SDHI) fungicides for the control of STB at growth stage 31 and 39 on two cultivars of autumn sown wheat. The protectant activity of triazole and SDHI fungicides was more effective on the flag leaf than the curative activity on leaf two. The addition of an SDHI to a $75 \%$ fixed rate of triazole was more effective at controlling STB infection than triazoles alone. The addition of SDHI fungicides also significantly increased yield. The highest mean yields were achieved with the addition of a third application at GS65.
\end{abstract}

Keywords septoria, protectant and curative activity, reduced triazole sensitivity, varietal resistance, grain yield.

\section{INTRODUCTION}

Septoria tritici blotch (STB) is a foliar disease of autumn and winter sown wheat (Triticum aestivum) caused by Zymoseptoria tritici (Desm.), a telemorph of the fungus Mycosphaerella graminicola (Fückel) J. Schrot.). It can result in severe yield losses, particularly when the top two leaves and to a lesser extent leaf three are affected (Thomas et al. 1989). STB is a wet weather disease that spreads from the stubble of the previous crop (Shaw \& Royal 1989), by way of ascospores that have the ability to travel several kilometres. This gives the potential for all wheat crops in a region to be infected from relatively few paddocks (FAR 2014). Further infection is spread via conidia during stem elongation and is aided by rain splash (Shaw \& Royal 1993), although any crop wetness such as dew or irrigation can spread spores by wind movement and leaf to leaf contact, even in dry weather (HGCA 2012).

With Zymoseptoria tritici resistance to strobilurin (quinone outside inhibitor, QoI) fungicides and reduced sensitivity to triazole demethylation inhibitor (DMI) fungicides (Fraaije et al. 2007; Stewart et al. 2014), it has become increasingly important to look to the succinate dehydrogenase inhibitors (SDHI) 
fungicides (FAR 2014) as the basis of new mixtures since they have a different mode of action. While the potential for the development of resistance to SDHI fungicides appears to be low (Stewart et al. 2014), SDHIs are at a moderate-high risk of resistance development (FAR 2014) because of incremental build up that may lead to cross-resistance (Sierotzki \& Scalliet 2013). Martin et al. (2005) gave fungicide recommendations aimed at reducing the development of resistance of no more than three applications of triazoles at full label rates and two applications of strobilurins in a season. The recommendation was for both products to be used preventatively, when disease levels were low, but disease pressure was high (Martin et al. 2005). Stewart et al. (2014) found widespread resistance to the strobilurin azoxystrobin and reduced sensitivity to the triazole epoxiconazole but no evidence of reduced sensitivity to the SDHI isopyrazam. Both Stewart et al. (2014) and van Toor et al. (2013) found that growers were routinely applying fungicides at lower than recommended rates. Resistance could be delayed by limiting the number of applications of the at-risk fungicide group, mixing or alternating the at-risk fungicide with another fungicide from a different cross-resistance group (Martin et al. 2005).

The objective of this project was to define the protectant and curative properties of triazole and triazole/SDHI mixtures applied at different rates for the control of STB. This information will enable development of appropriate dose rate guidelines to assist growers with disease management decisions and to protect the longevity of this new chemistry against the risk of resistance development.

\section{MATERIALS AND METHODS}

\section{Fungicide application}

Field trials were established in mid-April at Chertsey (cv. Savannah) and Lincoln (cv. Savannah and Torch) during the 2014-15 growing season. Each trial had a randomised complete block design with four replicates. Treatments were four rates of triazoles, epoxiconazole (Opus ${ }^{\circledR}$ ) and prothioconazole (Proline ${ }^{\circledR}$ ), and three rates of SDHIs, isopyrazam (Seguris Flexi ${ }^{\circledR}$ ) mixed with a $75 \%$ rate of Proline ${ }^{\circledR}$; fluxapyroxad
+ epoxiconazole (Adexar $\left.{ }^{\circledR}\right)$; and bixafen + prothioconazole (Aviator Xpro ${ }^{\circledR}$ ) mixed with a fixed $75 \%$ label rate of triazole at GS31 ( $1^{\text {st }}$ node on main stem) and GS39 (flag leaf emergence on main stem) (Table 1). An additional treatment of two applications of a 100\% label rate of fluxapyroxad + epiconazole received a third application of tebuconazole + prothioconazole (Prosaro ${ }^{\circledR}$ ) and pyraclostrobin $\left(\right.$ Comet $\left.^{\circledR}\right)$ applied at GS65 (anthesis).

\section{Disease assessments}

In all trials disease assessments were carried out at GS31, where 30 plants were randomly selected from across the trial area. Protectant activity was measured on leaf 1 as leaf emergence coincided with fungicide application at GS39. Curative activity was measured on leaf two as leaf emergence fell between fungicide applications at GS31 and GS39. Visual disease assessment based on the percentage of leaf area affected on the two newest leaves on the main stem showing STB infection was recorded (James 1971). Subsequent assessments were carried out at GS39, and GS39 + 14, 28, 42 and 56 days. At each assessment timing 10 main stems were randomly selected per plot and the \% disease infection was recorded on the top three leaves. From GS39+ 42 days, \% green leaf retention was also recorded. Disease assessments could not be made for leaf two at GS39 + 56 for cv. Savannah at the Kimihia Research Centre, Lincoln, as it had senesced. Plots were harvested with a Sampo ${ }^{\circledR}$ small plot combine, and yield components were analysed.

Statistical analysis was completed with GenStat $^{\circledR}$ (version 14, VSN International Ltd, UK) using a one-way ANOVA model. Standard curves were calculated by substituting the values for $\mathrm{Y}$ in the regression equation. Significant differences were separated using least significant difference (LSD) tests $(\mathrm{P}=0.05)$.

\section{RESULTS}

Disease progress is summarised in Figures 1-3. In the susceptible cv. Savannah disease initially developed slowly but STB infection increased to cover $59 \%$ and $90 \%$ of the flag leaf and leaf two respectively by anthesis (Figures $1 \mathrm{a} \& 1 \mathrm{~b}$ ). In the moderately resistant $\mathrm{cv}$. Torch, the equivalent 
levels of infection were 1 and 3\% (Figures 2a \& 2b). Disease control increased to a maximum as dose rate increased to $50 \%$ for the triazole fungicides epoxiconazole and prothioconazole on the flag leaf for Savannah (Figure 1a). Results showed protectant and curative properties of prothioconzaole were better at 50-100\% label rates than epoxiconazole $(\mathrm{P}<0.05)$. Protectant activity of both products was more effective on the flag leaf $(\mathrm{P}<0.01)$ (Figure 1a) than curative activity on leaf two $(\mathrm{P}<0.05)$ (Figures $1 \mathrm{~b})$. On leaf two, prothioconazole was significantly more effective than epoxiconazole with $12.4 \%$ STB infection with two $100 \%$ label rate applications of prothioconazole compared to $43.7 \%$ for epoxiconazole $(\mathrm{P}<0.05)$ (Figure $1 \mathrm{~b})$. Disease levels were very low and there were no significant differences in STB control for $\mathrm{cv}$. Torch with the exception of epoxiconazole on leaf $2(\mathrm{P}<0.05)$ (Figures 2a \& 2b).

Two applications of the SDHI fungicides isopyrazam, fluxapyroxad and bixafen mixed

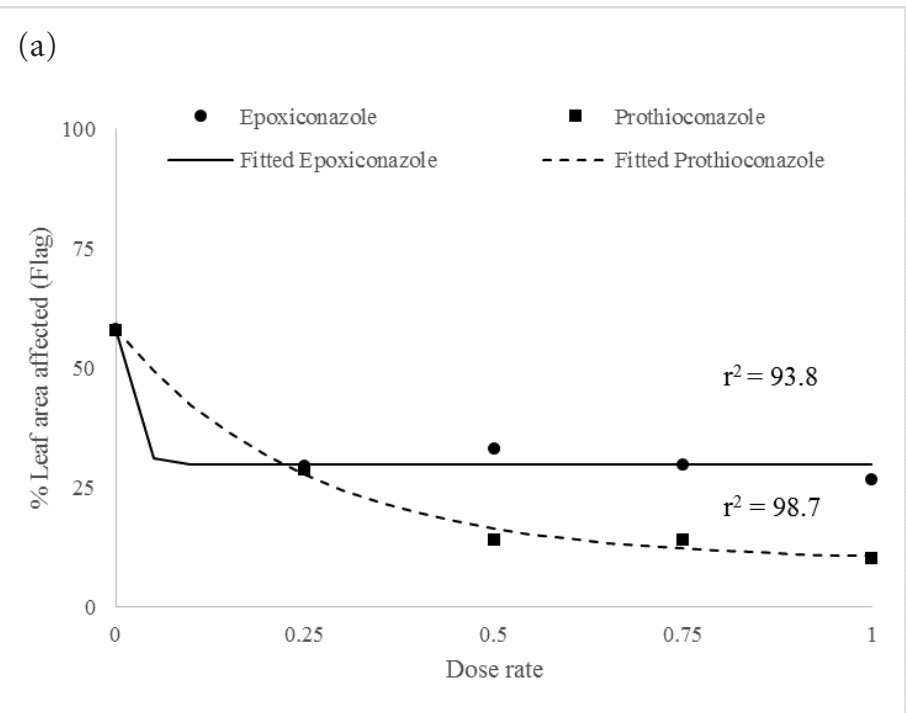

Figure 1 Septoria tritici blotch infection (\% leaf area affected) on (a) the flag leaf (mean for two sites) and (b) leaf 2 (mean for one site) from two fungicides (epoxiconazole or prothioconazole) applied at different concentrations $(0,0.25$, $0.5,0.75$ and 1 , where 1 is a full label rate) at growth stage 31 and 39 for Triticum aestivum cv. Savannah in 2014.

(b)

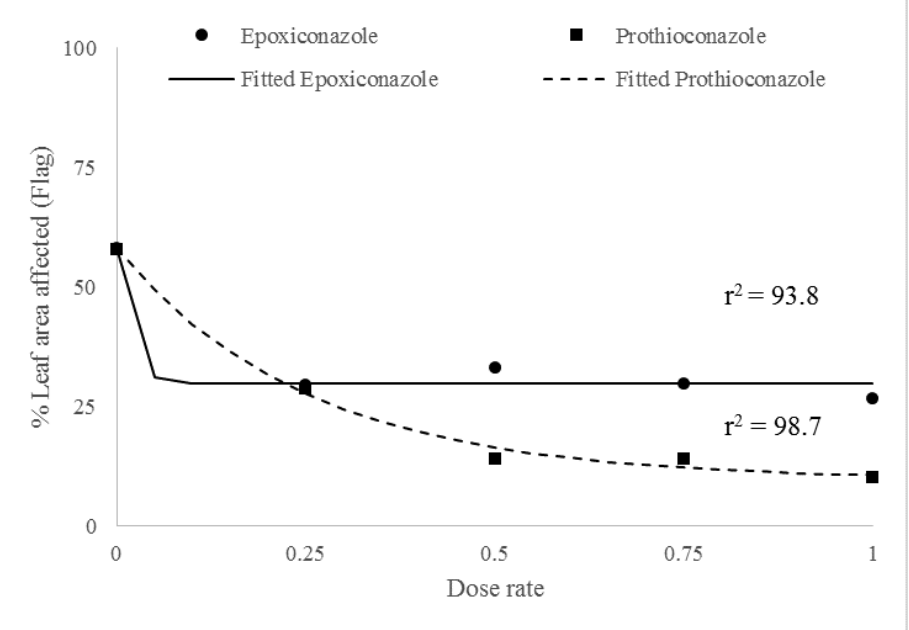


Table 1 Yield ( $\mathrm{t} / \mathrm{ha}$ ) in autumn sown wheat cv. Savannah (mean for two sites, Chertsey FAR Arable Site and Kimihia Research Centre, Lincoln) and cv. Torch (mean for one site, Kimihia Research Centre, Lincoln) treated with fungicides in different rates and combinations in 2014.

\begin{tabular}{|c|c|c|c|}
\hline Fungicides and active ingredient applied (g ai/ha) & Treatment (litres/ha) & Savannah & Torch \\
\hline Untreated & - & 9.9 & 14.2 \\
\hline Epoxiconazole, 31.3 & 0.25 & 9.9 & 15.1 \\
\hline Epoxiconazole, 62.5 & 0.5 & 10.3 & 15.3 \\
\hline Epoxiconazole, 93.8 & 0.75 & 10.7 & 15.3 \\
\hline Epoxiconazole, 125 & 1.0 & 10.7 & 15.3 \\
\hline Prothioconazole, 50 & 0.2 & 10.2 & 14.9 \\
\hline Prothioconaozle, 100 & 0.4 & 10.5 & 15.3 \\
\hline Prothioconazole, 150 & 0.6 & 10.3 & 15.3 \\
\hline Prothioconazole, 200 & 0.8 & 10.7 & 15.4 \\
\hline Isopyrazam, $62.5+$ prothioconazole, 100 & $0.5+0.6$ & 11.0 & \\
\hline Isopyrazam, $93.8+$ prothioconazole, 100 & $0.75+0.6$ & 11.2 & \\
\hline Isopyrazam, 125 + prothioconazole, 100 & $1.0+0.6$ & 10.7 & \\
\hline $\begin{array}{l}\text { Fluxapyroxad, } 19.4 \text { / epoxiconazole, } 19.4+ \\
\text { epoxiconazole, } 38.8\end{array}$ & $0.31+0.62$ & 10.8 & 15.7 \\
\hline $\begin{array}{l}\text { Fluxapyroxad, } 38.8 \text { / epoxiconazole, } 38.8+ \\
\text { epoxiconazole, } 28.2\end{array}$ & $0.62+0.45$ & 11.3 & 15.5 \\
\hline $\begin{array}{l}\text { Fluxapyroxad, } 58.8 \text { / epoxiconazole, } 58.8+ \\
\text { epoxiconazole, } 18.8\end{array}$ & $0.94+0.30$ & 10.9 & 15.6 \\
\hline $\begin{array}{l}\text { Fluxapyroxad, } 78.2 \text { / epoxiconazole, } 78.2+ \\
\text { epoxiconazole, } 9.4\end{array}$ & $1.25+0.15$ & 11.4 & 15.8 \\
\hline $\begin{array}{l}\text { Fluxapyroxad, } 78.2 \text { / epoxiconazole, } 78.2+ \\
\text { epoxiconazole, } 9.4^{1}\end{array}$ & $1.25+0.15$ & 11.9 & 15.9 \\
\hline $\begin{array}{l}\text { Bixafen, } 37.5 \text { / prothioconazole, } 75+ \\
\text { prothioconazole, } 48\end{array}$ & $0.5+0.32$ & 11.4 & \\
\hline $\begin{array}{l}\text { Bixafen, } 56.3 \text { / prothioconazole, } 112.5+ \\
\text { prothioconaozle, } 25.5\end{array}$ & $0.75+0.17$ & 11.2 & \\
\hline $\begin{array}{l}\text { Bixafen, } 75 \text { / prothioconaozle, } 150+ \\
\text { prothioconazole, } 4.5\end{array}$ & $1.0+0.03$ & 11.5 & \\
\hline Mean & & 10.8 & 15.3 \\
\hline P-value & & $<0.001$ & $<0.001$ \\
\hline $\mathrm{CV} \%$ & & 4.5 & 1.6 \\
\hline $\operatorname{LSD}(\mathrm{P}=0.05)$ & & 0.8 & 0.4 \\
\hline
\end{tabular}

with a fixed $75 \%$ rate of triazole (Figures 3a \& $3 \mathrm{~b})$ were significantly better than triazoles alone for cv. Savannah $(\mathrm{P}<0.01)$ (Figures 1a \& 1b). There was greater flexibility in SDHI application rate with $50-100 \%$ label rate providing optimum protection when mixed with a $75 \%$ triazole dose. For all three products, the protectant activity was more effective than curative activity when performance on the flag leaf (Figure 3a) and leaf two (Figure 3b) were compared.
The addition of an SDHI to a fixed $75 \%$ rate of triazole significantly increased grain yield compared to the untreated (Table 1). Increasing the SDHI rate did not significantly increase yield. Low rates of triazoles did not significantly increase yield relative to the untreated. Use of $75-100 \%$ label rates of triazoles achieved similar yields to SDHI treatments. (Table 1). In some cases the incidence of leaf rust (Puccinia recondita) limited the grain yield of plots treated 


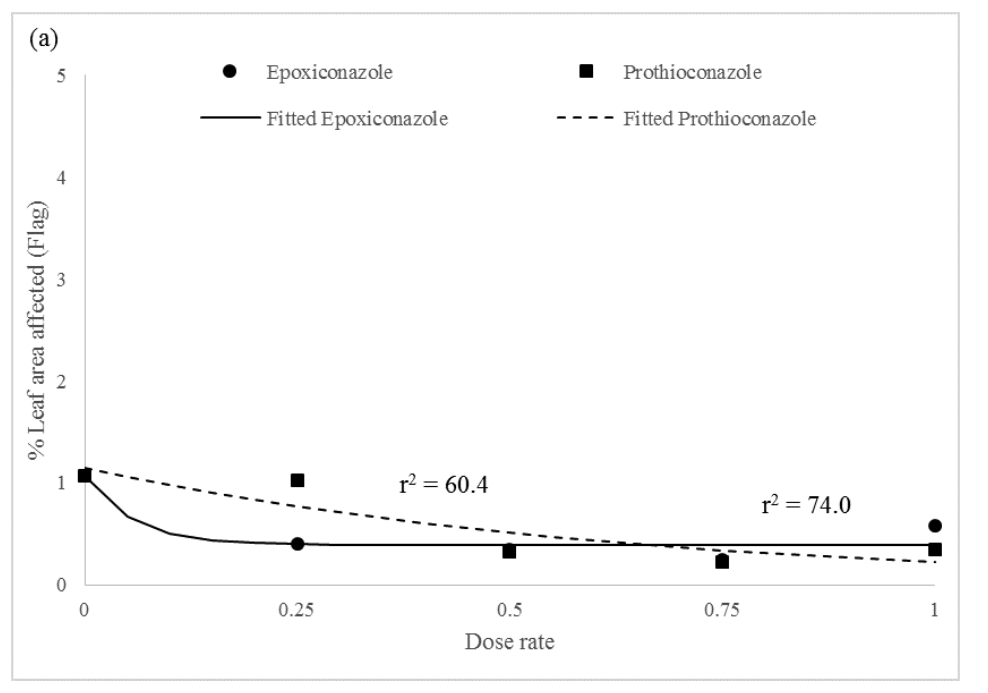

Figure 2 Septoria tritici blotch infection (\% leaf area affected) on (a) the flag leaf (mean for one site) and (b) leaf 2 (mean for one site) from two fungicides (epoxiconazole or prothioconazole) applied at different concentrations ( 0 , $0.25,0.5,0.75$ and 1 , where 1 is a full label rate) at growth stage 31 and 39 for Triticum aestivum cv. Torch in 2014.

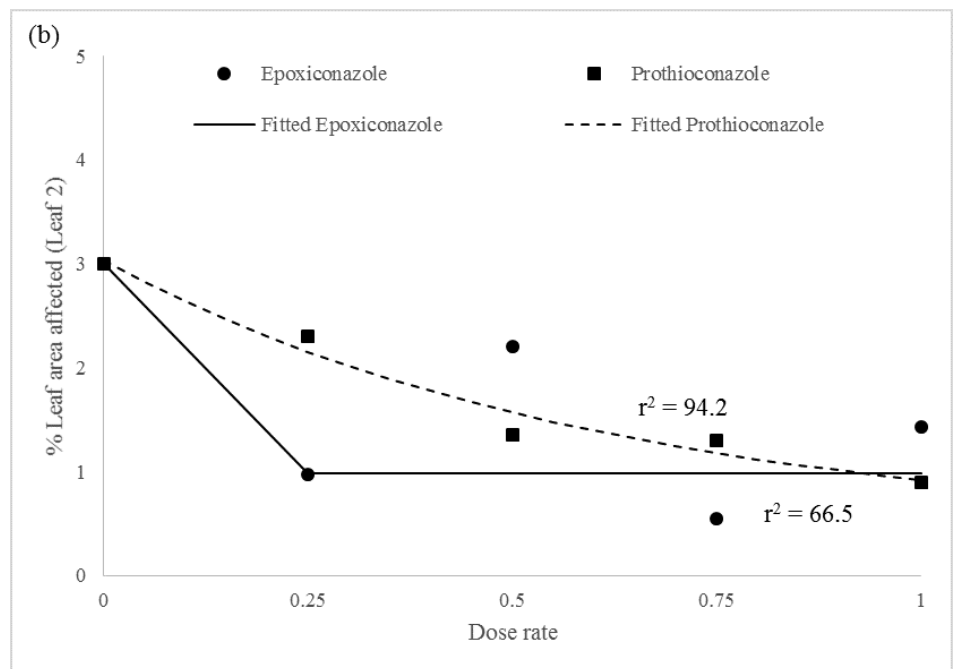

with prothioconazole at the Kimihia Research Centre. All fungicide treatments significantly increased yield in cv. Torch. Highest yield was achieved with application of tebuconazole, prothioconazole and pyraclostrobin at GS65.

\section{DISCUSSION}

Septoria tritici blotch has become a major fungal plant disease facing wheat growers in New Zealand (FAR 2014) particularly with the development of strobilurin resistance and reduced sensitivity to triazole fungicides altering disease management strategies. This work has mirrored that in the United Kingdom of Fraaije et al. (2007). Previously farmers could grow STB susceptible cultivars and protect them with fungicides (Brown 2012), even though more resistant cultivars were available (Marroni et al. 2006).

Reduced sensitivity of STB to triazole fungicides has meant higher rates of fungicide are required to obtain the same level of control prior to the detection of resistance mutations (FAR 2014). This was found by Stewart et al. (2014), where reduced sensitivity to epoxiconazole was 

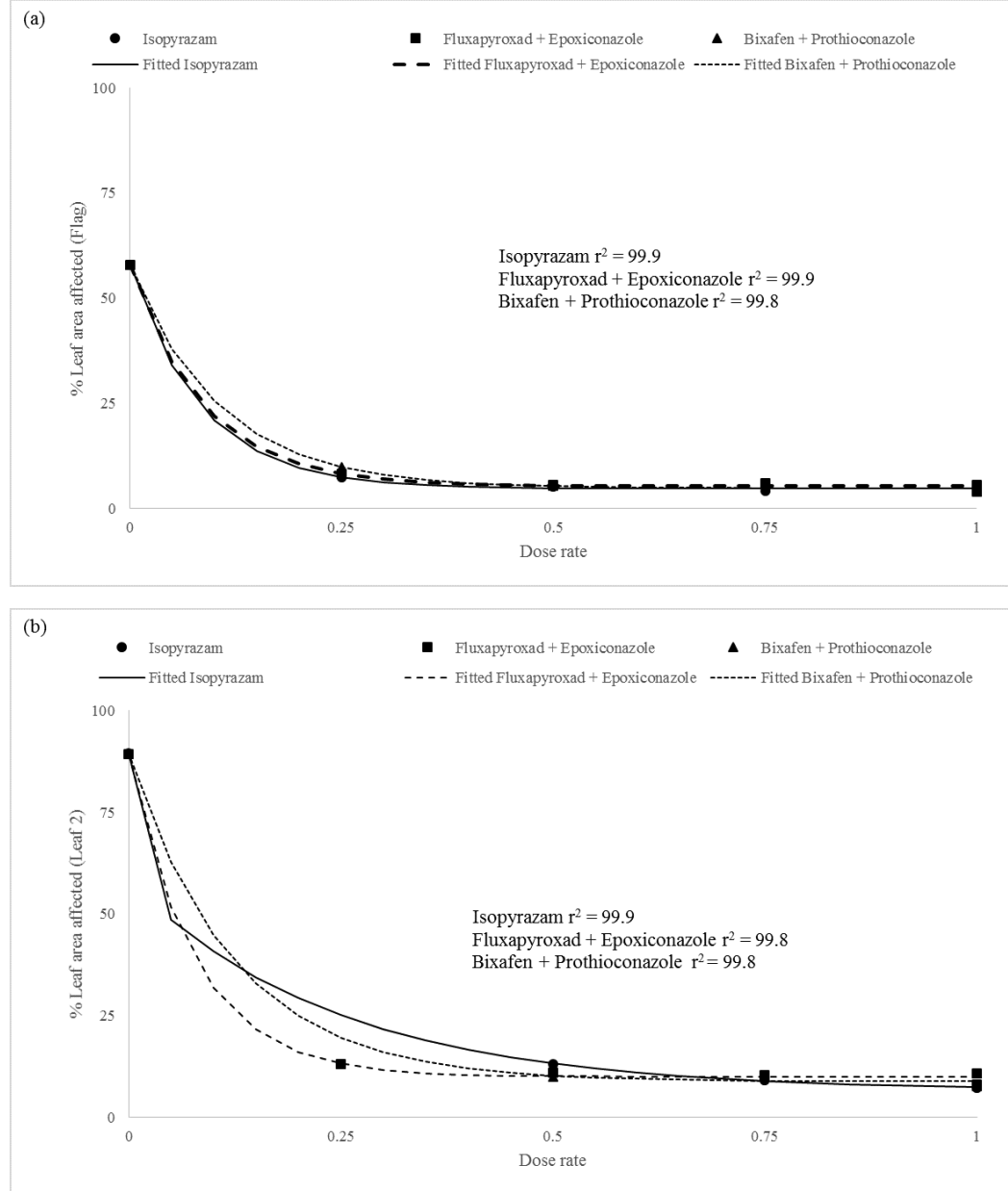

Figure 3 Septoria tritici blotch infection (\% leaf area affected) on (a) the flag leaf (mean for two sites) and (b) leaf 2 (mean for one site) from three fungicides (isopyrazam, fluxapyroxad and bixafen) applied at different concentrations $(0,0.25,0.5,0.75$ and 1 , where 1 is a full label rate) at growth stage 31 and 39 for Triticum aestivum cv. Savannah in 2014. widespread in the lower North Island of New Zealand, and Cools \& Fraaije (2008), who found a decline in the efficacy of some azoles against STB in the United Kingdom. This supports Martin et al. (2005), where resistance to triazole fungicides develops as a gradual decrease in sensitivity over time, which can be aided by repeated use of atrisk fungicides at reduced rates; as commonly practiced by growers (van Toor et al. 2013). However, van den Bosch et al. (2011) suggested that in most circumstances, a high fungicide dose will increase the speed at which resistance develops, placing further importance on the development of appropriate fungicide dose rate guidelines. Prothioconazole and epoxiconazole have the ability to control the fungus when it infected the leaf during the early stages of development (HGCA 2012). The protectant activity of both epoxiconazole and prothioconazole on the flag leaf was more effective than curative activity on leaf two because fungicide application occurred before disease development. This supports Godwin (1999), who found that while early fungicide application can provide protection for several weeks, it will not control established disease inoculum, and Godwin et al. (1994), who found epoxiconazole did not inhibit the early stages of STB infection. These results showed that the optimum rate of triazole application was 50$100 \%$ label rate. Under a high disease pressure scenario the optimum rate of triazole application was $75-100 \%$ label rate (FAR 2014). 
Results also showed prothioconazole was more effective at $50-100 \%$ label than epoxiconazole, which is consistent with Marroni et al. (2006) where epoxiconazole was less effective at controlling initial infection. There was a yield advantage with high rates of triazole application, but 25\% label rates of epoxiconazole offered no yield advantage compared to the untreated. At the Kimihia Research Centre, in some cases the activity of prothioconazole prevented further development of STB but was less effective at controlling leaf rust, resulting in reduced grain yield. Under the low disease pressure of the season in which these trials were carried out, results showed prothioconazole to be significantly more effective than epoxiconazole for cv. Savannah. The moderately resistant cultivar Torch had less disease, demonstrating the value of varietal resistance, which is important when selecting an appropriate disease management strategy.

As the strobilurins are no longer effective and triazoles have reduced sensitivity to STB, the use of SDHIs has become increasingly important and although they have activity on the same cell components as strobilurins, so far there has not been any cross resistance recorded (FAR 2014). When mixed in combination with a fixed $75 \%$ rate of triazole, the present study has shown SDHIs to be significantly more effective at STB control than triazoles alone. There were no significant differences in STB infection of plots treated with isopyrazam, fluxapyroxad and bixafen on the flag leaf. The present results concurred with research conducted in the United Kingdom that found SDHI/triazole mixes containing fluxapyroxad and bixafen had similar activity on STB and were superior to triazoles (HGCA 2014). The present results have shown that the use of SDHI/ triazole mixtures gave greater flexibility with rate and use of different fungicides than triazoles alone with little difference between 50-100\% label rates, under the low disease pressure in the 2014-15 season. Further research is needed to determine what might occur under high disease pressure conditions. All plots treated with SDHIs yielded similarly, but there was a $20 \%$ yield increase compared to the untreated for a two spray programme with cv. Savannah and an
$11 \%$ yield increase for $\mathrm{cv}$. Torch associated with a third fungicide application of tebuconazole and pyraclostrobin at GS65.

No two seasons are the same, and as such the risks of severe STB infection may vary from year to year. The disease management strategies for a susceptible variety such as cv. Savannah and a resistant variety such as cv. Torch are different. When constructing a fungicide programme the following factors need to be considered: reduced sensitivity of STB to triazoles, the efficacy of prothioconazole versus epoxiconazole and the advantages in yield and disease control achieved with SDHI/triazole mixtures.

\section{ACKNOWLEDGEMENTS}

This research was funded by the Foundation for Arable Research. Many thanks to FAR, Plant Diagnostics and PGG Wrightson Grain staff for data collection, NZ Arable for trial site preparation, drilling and harvest. Thanks also to Ian Harvey from Lincoln University, and Nick Poole and Richard Chynoweth from FAR for their input and help with interpretation and presentation of data.

\section{REFERENCES}

Brown JKM 2012. Improved resistance to septoria in superior varieties. HGCA Project Report 492. http://hgca.com/publications/2012/ april/24/improved-resistance-to-septoriavarieties.aspx (accessed 12/03/15).

Cools HJ, Fraaije BA 2008. Are azole fungicides losing ground against Septoria wheat diseases? Resistance mechanisms in Mycosphaerella graminicola. Pest Management Science 64: 681-684.

FAR 2014. Cropping Strategies - a summary of recent research findings: Cereal Disease Management (Revised 2014). Foundation for Arable Research, Christchurch, New Zealand. 19 pp.

Fraaije BA, Cools HJ, Kim SH, Motteram J, Clark WS, Lucas JA 2007. A novel substitution I381V in sterol 14 alpha-demethylase (CYP51) of Mycosphaerella graminicola is differentially selected by azole fungicides. Molecular Plant Pathology 8: 245-254. 
Godwin JR, Young JE, Hart CA 1994. ICIA5504: Effects of development of cereal pathogens. Brighton Crop Protection Conference - Pests and Diseases. Pp. 259-264.

Godwin JR, Bartlett DW, Heaney SP 1999. Azosystrobin: implications of biochemical mode of action. Pharmacokinetics and resistance management for spray programmes against septoria diseases of wheat. In: Lucas JA, Bowyer P, Anderson HM ed. Septoria on cereals: a study of pathosystems. CABI Publishing, Wallingford, UK. Pp. 299-315.

HGCA 2012. Septoria tritici in winter wheat. Topic sheet 113/Spring 2012 www.hgca.com/ media/.../ts113_septoria_tritici_in_winter_ wheat.pdf (accessed 12/03/2015).

HGCA 2014. Fungicide performance in wheat 2014: Wheat fungicide performance data 2014 (detailed slides). http://www.hgce.com/ crop-management/disease-managementfungicide-performance-in-wheat.aspx (accessed 12/03/2015).

James WC 1971. An illustrated series of assessment keys for plant diseases, their preparation and usage. Canadian Plant Disease Survey 51: 39-65.

Marroni MV, Viljanen-Rollinson SLH, Butler RC, Deng Y 2006. Fungicide timing for the control of Septoria tritici blotch of wheat. New Zealand Plant Protection 59: 160-165.

Martin NA, Beresford RM, Harrington KC ed. 2005. Pesticide resistance: Prevention and managament strategies 2005. New Zealand Plant Protection Society, Hastings, New Zealand. 166 pp.
Shaw MW, Royal DJ 1989. Airborne inoculum as a major source of Septoria tritici (Mycosphaerella graminicola) infections in winter wheat crops in the UK. Plant Pathology 38(1): 35-43.

Shaw MW, Royal DJ 1993. Factors determining the severity of epidemics of Mycosphaerella graminicola (Septoria tritici) on winter wheat in the UK. Plant Pathology 42: 882-899.

Sierotzki H, Scalliet G 2013. A review of current knowledge of resistance aspects for the next generation succinate dehydrogenase inhibitor fungicides. Phytopathology 103: 880-887.

Stewart TM, Perry AJ, Evans MJ 2014. Resistance of Zymoseptoria tritici to azoxystrobin and epoxiconazole in the lower North Island of New Zealand. New Zealand Plant Protection 67: 304-313.

Thomas MR, Cook RJ, King JE 1989. Factors affecting development of Septoria tritici in winter wheat and its effect on yield. Plant Pathology 38 (2): 246-257.

van den Bosch F, Paveley N, Shaw M, Hobbelen P, Oliver R 2011. The dose rate debate: does the risk of fungicide resistance increase or decrease with dose? Plant Pathology 60: 597606.

van Toor RF, Viljanen-Rollinson SLH, RahmanA, Teulon DAJ 2013. Agrichemical use on wheat and barley crops in New Zealand in 2008-09. New Zealand Journal of Crop and Horticultural Science 41: 9-22. 